\title{
In Vitro Activation of Cytotoxic T Lymphocytes By Muc1 Pulsed Dendritic Cells
}

\author{
Kryukov F. 1, 2,* , Očadlíková D. ${ }^{1,2}$, Kovářová L. ${ }^{1,2}$, Burešová I. ${ }^{1,2}$, Matějková E. ${ }^{1}$, Hájek R..$^{2,3}$ and \\ Michálek J. ${ }^{1,4}$ \\ ${ }^{1}$ University Cell Immunotherapy Center, Masaryk University, Kamenice 5, Brno 62500, Czech Republic \\ ${ }^{2}$ University Research Centre - The Czech Myeloma Group, Masaryk University, Brno, Czech Republic \\ ${ }^{3}$ Department of Hematooncology, University Hospital Brno, Czech Republic \\ ${ }^{4}$ Department of Pediatrics, University Hospital Brno, Czech Republic
}

\begin{abstract}
Multiple myeloma (MM) is one of the most common hematologic malignancies. Malignant plasma cells are only weakly immunogenic and the disease is accompanied by a defective function of the immune system. An important issue for immunotherapy of myeloma is the identification of appropriate tumor-associated antigens. Recently, MUC1 was detected on a majority of myeloma cell lines. We studied antigen-specific and HLA-A2-restricted cytotoxic activity against MUC1-positive ARH77 myeloma cell line in vitro. A HLA-A2 specific MUC1-derived nonapetide $\left({ }^{139}\right.$ TSAPDTRPA $\left.^{147}\right)$ was used as a tumor-associated antigen. Myeloma-specific cytotoxic activity of MUC1-reactive CTL was established by repeated stimulation of CTL via dendritic cells loaded with MUC1-derived nonapeptide. We were able to demonstrate that MUC1-reactive T cells can be identified and expanded using a relatively simple in vitro techniques. Antigen-specific stimulation via dendritic cells, immunomagnetic sorting and rapid expansion of CTL without loosing of their specific immune activity can be used clinically even in poorly immunogenic diseases such as MM.
\end{abstract}

\section{INTRODUCTION}

Multiple myeloma (MM) is a hematologic cancer arising from post-germinal matured B cells characterized by an excess of monotypic plasma cells in the bone marrow secreting monoclonal immunoglobulins with a concomitant decrease in normal immunoglobulins and lytic bone lesions [1]. Multiple myeloma has been considered a cancer with weak immunogenicity of the malignant cell population and defective function of the immune system [2,3]. The identification of tumor-associated antigens has opened new opportunities for the immunotherapy of MM patients.

MUC1 is a highly glycosylated type I transmembrane glycoprotein with an extracellular domain consisting of 2060 tandem repeats [4]. Its expression on normal cells is hidden from the immune system, and its aberrant glycosylation creates new epitopes on tumor cells that can be recognized by the immune system [5]. MUC1 is overexpressed in breast, ovarian, renal and pancreatic cancers [6-8]. MUC1 was also identified in the serum and the bone marrow of MM patients [9-11] as well as in most myeloma cell lines [12, 13]. It is a recognized tumor-associated antigen (TAA) and has been proposed as a candidate for anti-tumor vaccination $[6,7]$.

Vaccinations using dendritic cells pulsed with different TAAs were shown to be effective in patients with different cancer types including MM, B-cell lymphoma and malignant melanoma [14-18]. Dendritic cells (DCs) are the most potent

*Address Correspondence to this author at the University Cell Immunotherapy Center, Masaryk University, Kamenice 5, Brno 62500, Czech Republic; E-mail: f.kyukov@gmail.com antigen-presenting cells (APC) with a unique ability to initiate primary immune responses of $\mathrm{T}$ cells [19-24]. Pilot studies showed that the application of dendritic cells loaded with MUC1 nonapeptide was able to induce immune responses in patients with breast and ovarian cancer [6]. Recently, it has been demonstrated that autologous mature dendritic cells pulsed with HLA-A2-binding MUC1 peptides caused regression of metastatic sites in renal cell carcinoma patients [7]. MUC1-specific $\mathrm{CD}^{+}$cytotoxic $\mathrm{T}$ lymphocyte (CTL) response has also been detected in HLA-A2-positive myeloma patients [10].

In this study, we analyzed the antigen-specific HLA-A2restricted cytotoxic activity against ARH77 myeloma cell line in vitro using HLA-A2-specific MUC1-derived nonapetide $\left({ }^{139}\right.$ TSAPDTRPA $\left.^{147}\right)$ as a TAA. Activation of CTL was performed via MUC1-pulsed dendritic cells.

\section{MATERIALS AND METHODS}

\section{Cell Isolation and Cultures}

Peripheral blood was collected from HLA-A2 positive healthy volunteers after signing the informed consent approved by the local Ethical Committee. Peripheral blood mononuclear cells (PBMCs) were isolated with Histopaque 1077 (Sigma-Aldrich, Prague, Czech Republic) density gradient centrifugation from buffy coats of healthy donors. Isolated PBMC were cultivated in X-VIVO 10 (BioWhittaker, Walkersville, MD, USA) supplementing with $10 \%$ human AB-serum (Sigma-Aldrich, Prague, Czech Republic), 80U/ml DNAse (Boehringer, Mannheim, Germany) and $1 \mathrm{mM}$ L-glutamine (Sigma-Aldrich, Prague, Czech Republic). After 2-hours of incubation at $37^{\circ} \mathrm{C}$ incubator with $5 \%$ 
$\mathrm{CO}_{2}$ cells were separated to adherent and non-adherent fractions. Non-adherent fraction that was rich of $\mathrm{T}$ lymphocytes was incubated in complete medium (CM) containing $\mathrm{X}$ VIVO 15 (BioWhittaker, Walkersville, MD, USA), 10\% human AB-serum (Sigma-Aldrich, Praha, Czech Republic) and $10 \mathrm{IU} / \mathrm{ml}$ IL-2 (Proleukin, Chiron, Amsterdam, Netherlands). $10 \mathrm{IU} / \mathrm{ml} \mathrm{IL-2}$ was added every 2 to 3 days.

Adherent fraction with DC precursors was cultured for 6 days in X-VIVO 10 (BioWhittaker, Walkersville, MD, USA) supplemented with $20 \mathrm{ng} / \mathrm{ml}$ IL-4 (CellGenix, Freiburg, Germany) and $100 \mathrm{U} / \mathrm{ml}$ GM-CSF (CellGenix, Freiburg, Germany). DC medium with cytokines was replaced every 2 days and cell morphology was monitored by light microscope $[17,18]$. After 6 days of DC culture, maturation agents 10 ng/ml TNF- $\alpha$ (Bender Medsystems Diagnostics, Vienna, Austria), $10 \mathrm{ng} / \mathrm{ml}$ IL-1 $\beta$ (CellGenix, Freiburg, Germany), $250 \mathrm{ng} / \mathrm{ml} \mathrm{PgE}_{2}$ (Prostin, Pfizer Inc., NY, USA), $1 \mathrm{ug} / \mathrm{ml}$ TLR-ligand R848 (Invivogen, California, USA) and 5000 IU/ml IFN- $\gamma$ (Gentaur, Brussels, Belgium) were added [2528]. Cells were harvested after overnight incubation.

\section{Peptide Antigens}

HLA-A2 specific MUC-1-derived synthetic peptide (amino acids ${ }^{139}$ TSAPDTRPA $^{147}$ ) (Proimmune, Oxford, UK) was used as a TAA. An HLA-A2 binding HIV-1 reverse transcriptase synthetic peptide (amino acids ${ }^{476}$ ILKEP $\mathrm{VHGV}^{484}$ ) was used as a negative control (Proimmune, Oxford, UK) $[6,28]$. Matured dendritic cells were pulsed for two hours with $1 \mu \mathrm{g} / \mathrm{ml}$ peptide on day 7 of DC culture as previously described [6].

\section{Stimulation and Restimulation of T Lymphocytes}

On day 7 peptide-pulsed DCs were mixed with T lymphocytes at the ratio 20:1 (T cells:DCs). The remaining DCs were frozen and used for $\mathrm{T}$ lymphocyte restimulation at the ratio 2:1 (T cells:DCs) after 7 days following the initial stimulation as previously described [29].

\section{IFN- $\gamma$ Detection and Immunomagnetic Separation}

The IFN- $\gamma$ production was performed with Secretion Assay Cell Enrichment and Detection Kit (MACS Reagens, Miltenyi Biotec, Bergisch Gladbach, Germany).

Cell separation was performed 24 hours after restimulation of T cells with peptide-pulsed DCs (MUC1 or pol HIV1). Following the manufacturer's instructions, immunomagnetic beads were used for sorting with VarioMACS cell separation system (MACS Reagents, Miltenyi Biotec, Bergisch Gladbach, German). IFN- $\gamma^{+} \mathrm{T}$ lymphocytes were labeled with paramagnetic beads from Secretion Assay Cell Enrichment and Detection Kit (MACS Reagens, Miltenyi Biotec, Bergisch Gladbach, Germany) [28]. All solutions were kept on ice to prevent capping and patching of antibodies on the surface of labeled cells. To increase the purity, IFN- $\gamma^{+}$-fraction containing antigen-reactive T cells was separated twice. IFN- $\gamma^{+}$fraction was then expanded in vitro. Cell purity was checked by flow cytometry.

\section{Flow Cytometry}

Cells were stained using fluorescein isothiocyanate (FITC)-, phycoerythrin-cyanine 7 (PC7)- or phycoerythrin
(PE)-conjugated monoclonal antibodies against CD4, CD8, CD3, CD 80, CD 86, CD 83, HLA DR (all purchased from Immunotech, Marseille, Francie) and IFN- $\gamma$ (Miltenyi Biotec, Bergisch Gladbach, German). Flow cytometry analyses were performed with CytomicsTM FC 500 (Beckman Coulter, Miami, Florida, USA].

\section{Expansion of IFN- $\gamma^{+}$MUC1-reactive T lymphocytes}

IFN- $\gamma^{+}$MUC1-reactive T lymphocytes were expanded in vitro with $75 \mu \mathrm{g} / \mathrm{ml}$ of anti-CD3/anti-CD28 monoclonal antibodies (Dynabeads CD3/CD28 T cell Expander, Invitrogen, California, USA]. Cultured cells were plated $\left(50 \times 10^{3} \mathrm{~T}\right.$ cells per well) into 96 -well plates in complete medium supplemented with $500 \mathrm{IU} / \mathrm{ml}$ interleukin-2 (Proleukin, Chiron, Amsterdam, Netherlands). Cultures were fed with fresh medium as needed and IL-2 was added twice a week. Irradiated allogenic PBMCs (30 Gy) were added weekly.

\section{Cytotoxicity Assay}

T cell-mediated cytotoxicity assay was performed with the LIVE/DEAD ${ }^{\circledR}$ Cell-Mediated Cytotoxicity Kit (Invitrogen Corporation, Carlsbad,USA). MUC1-positive ARH77 myeloma cell line was used as a target and was labeled with 3,3'-dioctadecyloxacarbocyanine (DiOC) as previously described [31]. To test their specificity, MUC1-reactive T cells (effector cells) were mixed with target cells at different ratios and incubated for 4 hours. Dead target cells were indicated with propidium iodide (PI) staining [54]. Maximum target cell lysis was measured after irradiation (60 Gy) of ARH77 cells and spontaneous target cell lysis was measured after incubation without effectors. As a negative control, thirdparty PBMCs were cultivated with MUC1-specific CTL. The percentage of cell-mediated cytotoxicity was calculated by the following formula: cytotoxicity $(\%)=($ experimental target cell lysis - spontaneous target cell lysis)/(maximum target cell lysis - spontaneous target cell lysis $) \times 100$.

\section{Statistical Analysis}

Statistical analysis was performed with software package SPSS $16.0\left(^{\circ}\right.$ SPSS Inc.). Results were submitted with descriptive statistics and were reported as Mean \pm SD. Significance was estimated by nonparametric tests. Two independent sample analyses were performed with Mann-Whitney U test. Wilcoxon signed-rank test was used to compare the distributions of two related variables.

\section{RESULTS}

\section{Activation of T lymphocytes by MUC1-pulsed Dendritic Cells}

DCs were generated from PBMCs using GM-CSF and IL-4 and were activated by addition of TNF $\alpha$ as previously described. Maturation of DCs with TNF $\alpha$ led to high expression of CD80, CD86, HLA-DR ( $\geq 85 \%)$ and at least intermediate expression of CD83 ( $\geq 25 \%)$ molecules. Matured DCs were loaded with nonapeptide antigen $\left({ }^{139}\right.$ TSAPDTRPA $\left.^{147}\right)$ derived from MUC1 protein. MUC1-pulsed DCs served as stimulators of autologous $\mathrm{CD}^{+}$and $\mathrm{CD}^{+} \mathrm{T}$ lymphocytes. After repeated stimulation of $\mathrm{T}$ cells, the IFN- $\gamma^{+}$subset of $\mathrm{CD}^{+} \mathrm{CD}^{+}$and $\mathrm{CD}^{+}{ }^{+} \mathrm{CD} 8^{+}$reached $1.31 \% \pm 0.15 \%$ and $1.05 \% \pm 0.12 \%$, respectively. In the control group with HIV-1 peptide, the IFN $-\gamma^{+}$subset of $\mathrm{CD} 3{ }^{+} \mathrm{CD} 4^{+}$and $\mathrm{CD} 3{ }^{+} \mathrm{CD} 8^{+}$was 


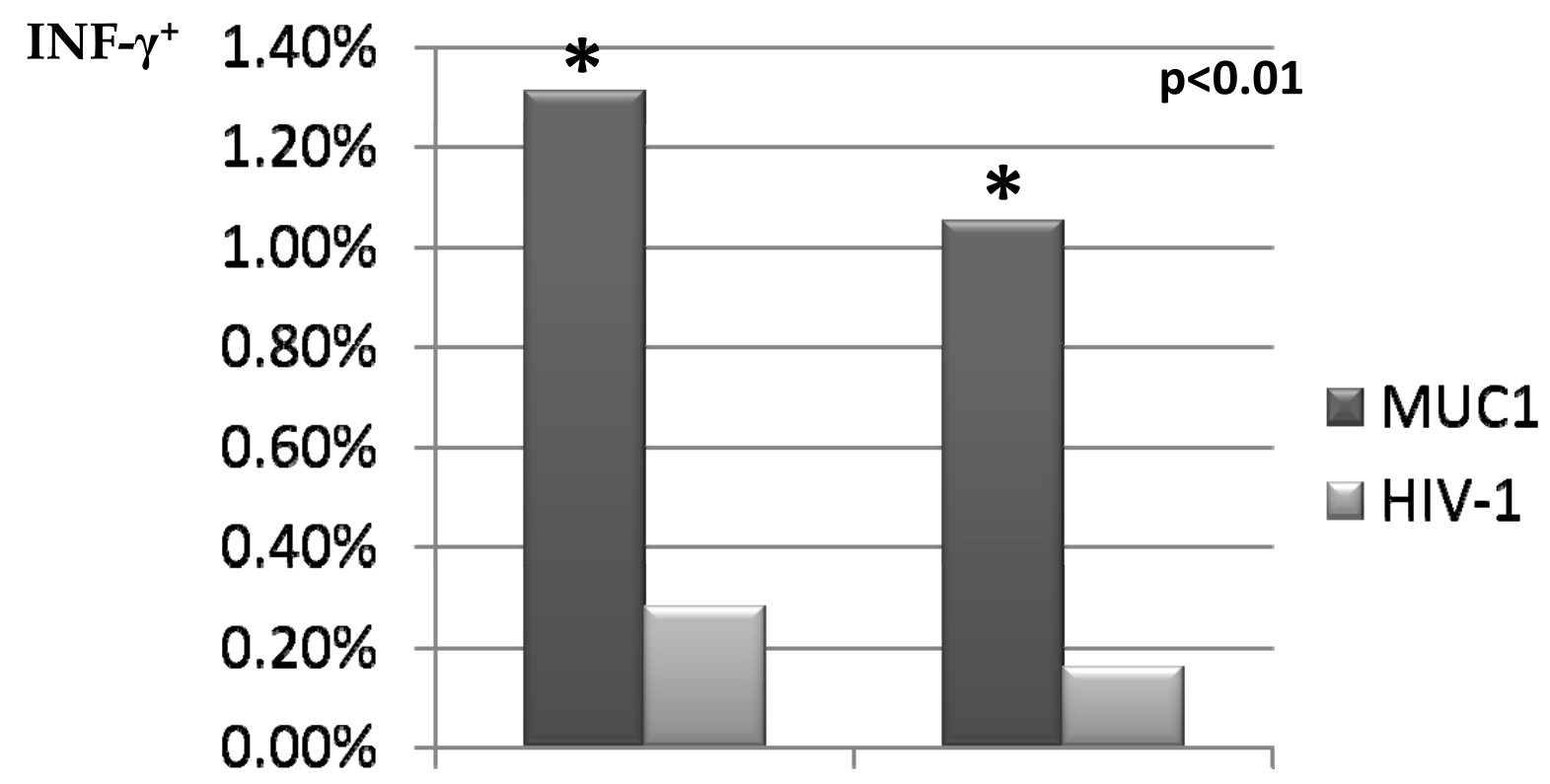

\section{CD3CD4 CD3CD8}

Fig. (1). IFN- $\gamma$ production of MUC1-reactive T cells.

Matured dendritic cells were loaded with nonapeptide antigen $\left({ }^{139}\right.$ TSAPDTRPA $\left.^{147}\right)$ derived from the MUC1 protein and used to simulate autologous T cells. After 7 days following the initial stimulation, T lymphocytes were restimulated with the same antigen-pulsed DCs. HIV1-derived peptide $\left({ }^{476} \mathrm{ILKEPVHGV}{ }^{484}\right)$ was used as negative control. Activation of $\mathrm{CD} 3{ }^{+} \mathrm{CD} 4^{+}$and $\mathrm{CD} 3{ }^{+} \mathrm{CD} 8^{+} \mathrm{T}$ lymphocytes in the experimental (MUC1) and the control (HIV-1) groups was measured by the IFN- $\gamma$ production. Flow cytometry analysis was performed after $24-$ hours of restimulation with MUC1- or HIV-1-pulsed DCs. All data were shown in the text.

$0.28 \% \pm 0.019 \%$ and $0.16 \% \pm 0.037 \%$, respectively. The differences between experimental and control groups were significant $(\mathrm{p}<0.01)$ (Fig. 1).

\section{Immunomagnetic Separation of MUC1-reactive T lym- phocytes}

To enrich the MUC1-reactive population of $\mathrm{T}$ cells, the IFN $-\gamma^{+} \mathrm{T}$ cells were separated in the magnetic field. Prepurification IFN $-\gamma^{+}$subset of $\mathrm{CD}^{+} \mathrm{CD}^{+}$and $\mathrm{CD}^{+}{ }^{+} \mathrm{CD} 8^{+} \mathrm{T}$ cells was $1.31 \% \pm 0.15 \%$ and $1.05 \% \pm 0.12 \%$, respectively. To increase the purity of MUC1-reactive T cells the IFN- $\gamma^{+}$fraction was separated twice. After double separation the MUC1-reactive T cells were enriched to $66.94 \% \pm 7.19 \%$ of IFN $-\gamma^{+} \mathrm{CD}^{+} \mathrm{CD}^{+}$and $64.59 \% \pm 6.03 \% \mathrm{IFN}-\gamma^{+} \mathrm{CD}^{+} \mathrm{CD}^{+} \mathrm{T}$ cells. The negative fraction contained less then $0.5 \%$ of IFN$\gamma^{+} \mathrm{T}$ cells after double immunomagnetic separation (Fig. 2).

\section{Expansion of IFN- $\gamma^{+}$MUC1-Reactive T lymphocytes}

Expansion of MUC1-reactive IFN- $\gamma^{+}$T lymphocytes after immunomagnetic separation was started with $0.1-0.3 \times 10^{6} \mathrm{~T}$ cells. In all experiments $\mathrm{T}$ cells were successfully expanded to at least $1.0 \times 10^{7} \mathrm{~T}$ cells within 8-12 days with antiCD3/anti-CD28 beads.

\section{Cytotoxicity Assay}

To confirm the specificity of MUC1-reactive T cells, the cytotoxicity test with ARH77 MUC1-positive myeloma cell line as target cells was performed. Expanded MUC1-reactive $\mathrm{T}$ cells were used as effectors. Specific cytotoxicity of MUC1-reactive T cells was measured with flow cytometrybased test. At a ratio 20:1 (effector:target cells) cytotoxicity of IFN- $\gamma^{+}$T lymphocytes vs. ARH77 reached $17.16 \% \pm 5.13$ $\%$ compared to non-specific killing of allogenic PBMC which was $0.79 \% \pm 0.39 \%$. At a ratio $40: 1 \mathrm{IFN}-\gamma^{+} \mathrm{T}$ cells were able to kill $36.14 \% \pm 6.51 \%$ of ARH77 MUC1-positive target cells while the cytotoxicity against allogenic PBMC remained negligible $0.77 \% \pm 0.38 \%$ (Fig. 3). The data demonstrate a specific cytotoxic potential of expanded MUC1reactive $\mathrm{T}$ cells that are able to recognize MUC1 and kill target cells carrying that antigen.

\section{DISCUSSION}

Multiple myeloma has been considered as a cancer with weak immunogenicity of the malignant cell population and a defective function of the immune system, including dendritic cells and $\mathrm{T}$ cells $[2,3]$. MUC1-specific $\mathrm{CD}^{+} \mathrm{T}$ cells response was recognized in $40 \%$ of HLA-A2-positive myeloma patients [10]. MUC1 expression was found in $92 \%$ of myeloma samples [36]. Based on our previous observations $[29,30]$ and other studies $[5,6,10,11]$ we were able to demonstrate that MUC1-pulsed DCs that are not immunocompromised by the original cancer environment can induce myeloma-specific CTLs. Functional DCs are critical for optimal antigen presentation and for initiation of T-lymphocyte response. Significant increase of T-lymphocyte IFN- $\gamma$ production confirmed immunogenic activity of MUC1-pulsed DCs.

$\mathrm{CD}^{+} \mathrm{T}$ cells can differentiate into cytotoxic TLs which are able to lyse TAA-expressing cells. Activation of $\mathrm{CD}^{+} \mathrm{T}$ cells requires two steps: presentation of antigenic peptides on professional APC and helper function which is provided by $\mathrm{CD}^{+} \mathrm{T}$ cells [32-36]. In our study anti-tumor activity of 
A.

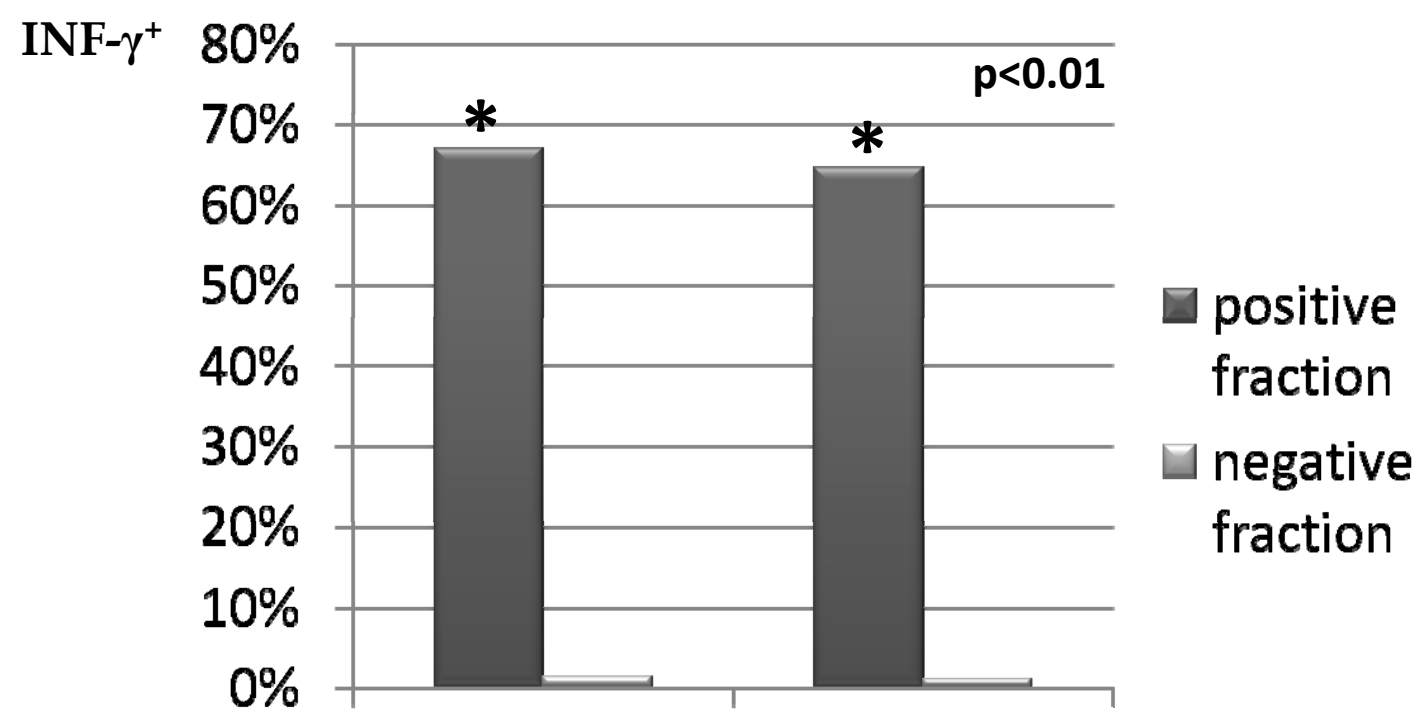

CD3CD4 CD3CD8

B.
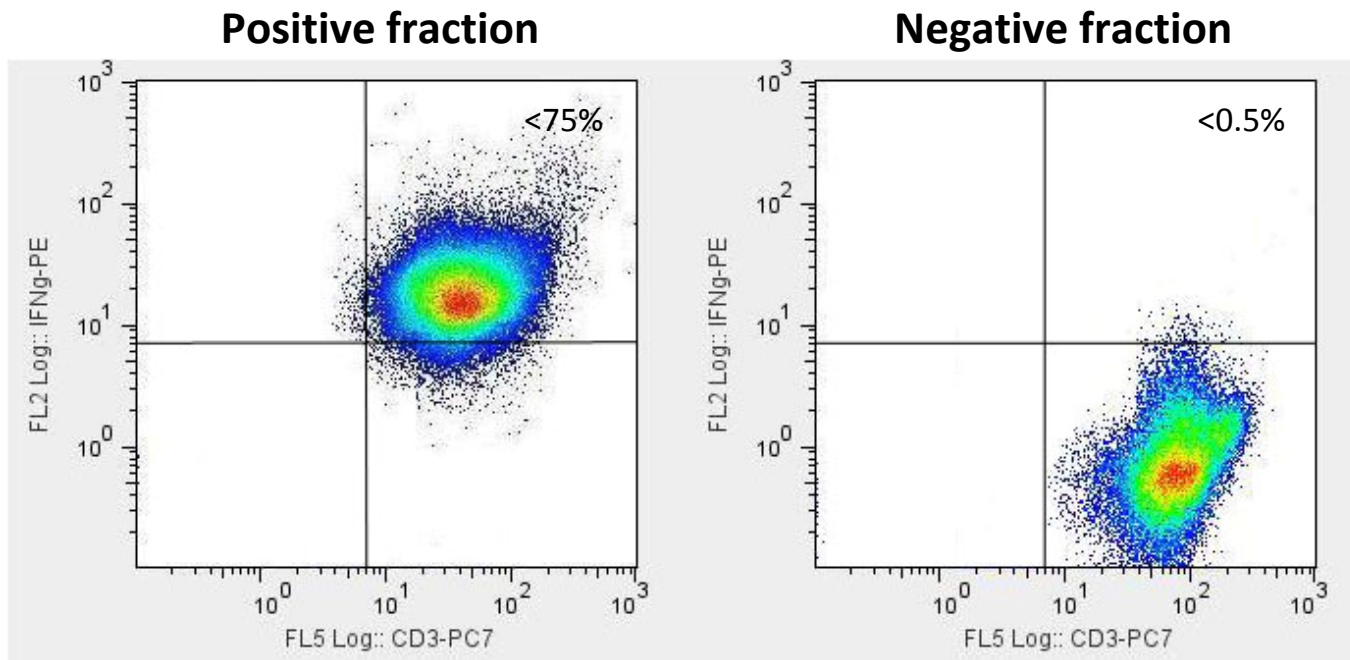

Fig. (2). Separation of MUC1-reactive T cells.

Comparison of IFN $-\gamma^{+}$subsets of $\mathrm{CD}^{+} \mathrm{CD} 4^{+}$and $\mathrm{CD} 3^{+} \mathrm{CD} 8^{+} \mathrm{T}$ lymphocytes in positive and negative fractions. Immunomagnetic separation was performed twice. Panel A demonstrates percentages of IFN- $\gamma$ producing cells of each subset. Panel B demonstrates staining of gated lymphocytes with PE-conjugated anti-IFN- $\gamma$ and PC7-conjugated anti-CD3 from representative experiment. All data were shown in the text.

MUC1-specific IFN- $\gamma^{+} \mathrm{T}$ cells was evaluated in vitro. The cytotoxicity test was used as an integrative indicator of antitumor immune response. MUC1-specificity of cytotoxic attack was associated with MUC1 expression by the myeloma cell-line ARH77.

Recently, it has been demonstrated that cytotoxic T lymphocytes activated by specific tumor antigen and producing IFN- $\gamma$ can be captured and used for targeted immunotherapy of cancer. In our previous study we adapted this strategy further to demonstrate that activated IFN- $\gamma^{+} \mathrm{T}$ cells can be expanded to large numbers without loss of tumor specificity using PHA [29]. PHA serves as a potent stimulus for $\mathrm{T}$ cell expansion but, it has been also demonstrated that long-term repeated PHA stimulation of $\mathrm{T}$ cells may lead to their exhaustion [37]. Thus, short term PHA stimulation or other strategies that employ anti-CD3/CD28 beads can be used for rapid clinical-grade $T$ cell expansion [38]. In this study we were able to demonstrate the possibility rapid and efficient CTL expansion technology without loosing of their specific immune activity. Anti-CD3/CD28 based expansion of CTLs can be an important ingredient of successful CTL-targeted therapy.

\section{CONCLUSION}

In this study, we were able to demonstrate that MUC1specific $\mathrm{T}$ cells can be identified and expanded using a rela- 


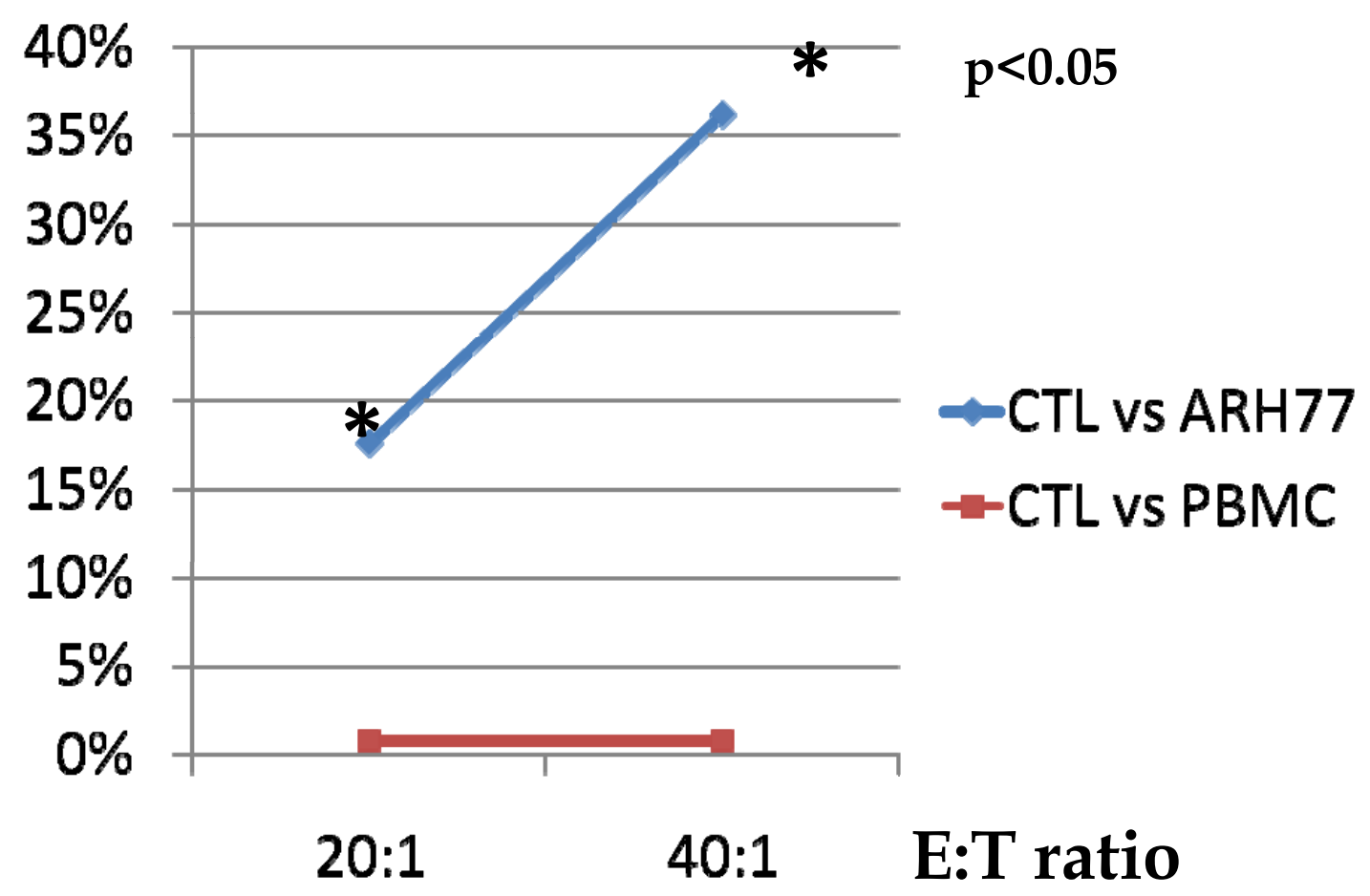

Fig. (3). Cytotoxic activity of MUC1-specific CTL against ARH77 myeloma cell line.

T cell-mediated cytotoxicity was performed with expanded MUC1-reactive T cells as effectors (E). DiOC-labeled MUC1-positive ARH77 myeloma cells were used as target cell (T). PBMCs were used as a negative control target. All data were shown in the text.

tively simple in vitro technique consisting of antigen-specific stimulation via DC, immunomagnetic sorting and rapid expansion. Such approach can be used clinically even in poorly immunogenic diseases such as MM. In summary, MUC1pulsed DCs and MUC1-specific CTL could be good candidates for future clinical trials. In case of multiple myeloma the MUC1-specific vaccination (DC- or CTL-based) can be a great benefit leading to alert the immune system against such tumor antigen and possible myeloma progression.

\section{ACKNOWLEDGMENT}

This study was supported with grant MSMT LC06027 and IGA MZCR 1A8709-5.

\section{REFERENCES}

[1] Kuehl WM, Bergsagel PL. Multiple myeloma: evolving genetic events and host interactions. Nat Rev Cancer 2002; 2(3): 175-87.

[2] Martín-Ayuso M, Almeida J, Pérez-Andrés M, et al. Peripheral blood dendritic cell subsets from patients with monoclonal gammopathies show an abnormal distribution and are functionally impaired. Oncologist 2008; 13(1): 82-92.

[3] Pratt G, Goodyear O, Moss P. Immunodeficiency and immunotherapy in multiple myeloma. Br J Haematol 2007; 138(5): 563-79.

[4] Gendler S, Taylor-Papadimitriou J, Duhig T, Rothbard J, Burchell $\mathrm{J}$-A. A highly immunogenic region of a human polymorphic epithelial mucin expressed by carcinomas is made up of tandem repeats. $\mathbf{J}$ Biol Chem 1988; 263: 12820-23.

[5] Finn OJ, Jerome KR, Henderson RA, et al. MUC-1 epithelial tumor mucin-based immunity and cancer vaccines. Immunol Rev 1995; 145: 61-89.

[6] Brossart P, Wirths S, Stuhler G, et al. Induction of cytotoxic Tlymphocyte responses in vivo after vaccinations with peptidepulsed dendritic cells. Blood 2000; 96: 3102-08.

[7] Wierecky J, Mueller MR, Brossart P, et al. Immunologic and clinical responses after vaccinations with peptide-pulsed dendritic cells in metastatic renal cancer patients. Cancer Res 2006; 66: 5910-18.
[8] Moniaux N, Andrianifahanana M, Brand RE, Batra SK. Multiple roles of mucins in pancreatic cancer, a lethal and challenging malignancy. Br J Cancer 2004; 91(9): 1633-8.

[9] Brossart P, Wirths S, Brugger W, Kanz L. Dendritic cells in cancer vaccines. Exp Hematol 2001; 29: 1247-55.

[10] Takahashi T, Makiguchi Y, Yachi A, et al. Expression of MUC1 on myeloma cells and induction of HLA-unrestricted CTL against MUC1 from a multiple myeloma patient. J Immunol 1994; 153: 2102-09.

[11] Choi C, Witzens M, Bucur M, et al. Enrichment of functional CD8 memory T cells specific for MUC1 in bone marrow of patients with multiple myeloma. Blood 2005 1; 105(5): 2132-4.

[12] Treon SP, Raje N, Anderson KC. Immunotherapeutic strategies for the treatment of plasma cell malignancies. Semin Oncol 2000; 27 598-613.

[13] Burton J, Mishina D, Gold DV, et al. Epithelial Mucin-1 (MUC1) expression and MA5 anti-MUC1 monoclonal antibody targeting in multiple myeloma. Clin Cancer Res 1999; 5: 3065-72.

[14] Timmerman JM, Levy R. Dendritic cell vaccines for cancer immunotherapy. Annu Rev Med 1999; 50: 507-29.

[15] Nestle FO, Alijagic S, Gilliet M, et al. Vaccination of melanoma patients with peptide- or tumor lysate-pulsed dendritic cells. Nat Med 1998; 4: 328-32.

[16] Hsu FJ, Benike C, Fagnoni F, et al. Vaccination of patients with Bcell lymphoma using autologous antigen-pulsed dendritic cells. Nat Med 1996; 2: 52-8

[17] Thurner B, Haendle I, Roder C, et al. Vaccination with MAGE3A1 peptide-pulsed mature, monocyte-derived dendritic cells expands specific cytotoxic $\mathrm{T}$ cells and induces regression of some metastases in advanced stage IV melanoma. J Exp Med 1999; 190 1669-78.

[18] Bendandi M, Gocke CD, Kobrin CB, et al. Complete molecular remissions induced by patient-specific vaccination plus granulocyte-monocyte colony-stimulating factor against lymphoma. Nat Med 1999; 5: 1171-77.

[19] Steinman RM. The dendritic cell system and its role in immunogenicity. Annu Rev Immunol 1991; 9: 271-96.

[20] Banchereau J, Steinman RM. Dendritic cells and the control of immunity. Nature 1998; 392: 245-52. 
[21] Porgador A, Gilboa E. Bone-marrow-generated dendritic cells pulsed with a class I-restricted peptide are potent inducers of cytotoxic T lymphocytes. J Exp Med 1995; 182: 255-60.

[22] Zitvogel L, Mayordomo JI, Tjandrawan T, et al. Therapy of murine tumors with tumor peptide-pulsed dendritic cells: dependence on $\mathrm{T}$ cells, B7 costimulation, and T helper cell 1-associated cytokines. J Exp Med 1996; 183: 87-97.

[23] Paglia P, Chiodoni C, Rodolfo M, Colombo MP. Murine dendritic cells loaded in vitro with soluble protein prime cytotoxic T lymphocytes against tumor antigen in vivo. J Exp Med 1996; 183: 317 22.

[24] Brossart P, Goldrath AW, Butz EA, Martin S, Bevan MJ. Adenovirus mediated delivery of antigenic epitopes into DC by a means of CTL induction. J Immunol 1997; 158: 3270-76.

[25] Büchler T, Hajek R, Bourkova L, et al. Generation of antigenloaded dendritic cells in a serum-free medium using different cytokine combinations. Vaccine 2003; 21: 877-82.

[26] Zobywalski A, Javorovic M, Frankenberger B, et al. Generation of clinical grade dendritic cells with capacity to produce biologically active IL-12p70. J Transl Med 2007; 5: 18.

[27] Jarnjak-Jankovic S, Hammerstad H, Saebøe-Larssen S, Kvalheim G, Gaudernack G. A full scale comparative study of methods for generation of functional dendritic cells for use as cancer vaccines. BMC Cancer 2007; 7: 119.

[28] Vonderheide RH, Hahn WC, Schultze JL, Nadler LM. The telomerase catalytic subunit is a widely expressed tumor-associated antigen recognized by cytotoxic T lymphocytes. Immunity 1999; 10: 673-90.

[29] Ocadlikova D, Zahradova L, Kovarova L, et al. Isolation and expansion of allogeneic myeloma-specific interferon-gamma produc- ing T cells for adoptive immunotherapy. Med Oncol 2006; 23: 37784 .

[30] Ocadlikova D, Kovarova L, Hajek R, Michalek J. [The preparation of myeloma-specific $\mathrm{T}$ cells activated with dendritic cells loaded with nonapeptides derived from mucin protein MUC1 and catalytic subunit of telomerase hTERT]. Klin Onkol 2008; 21(2): 59-65.

[31] Chang L, Gusewitch GA, Nehlsen-Cannarella SL, et al. Rapid flow cytometric assay for the assessment of natural killer cell activity. J Immunol Methods 1993; 166: 45-54.

[32] Santana MA, Esquivel-Guadarrama F. Cell biology of T cell activation and differentiation. Int Rev Cytol 2006; 250: 217-74.

[33] Shen L, Rock KL. Priming of T cells by exogenous antigen crosspresented on MHC class I molecules. Curr Opin Immunol 2006; 18: 85-91.

[34] Bryant P, Ploegh H. Class II MHC peptide loading by the professionals. Curr Opin Immunol 2004; 16: 96-102.

[35] Becker C, Pohla H, Frankenberger B, et al. Adoptive tumor therapy with $\mathrm{T}$ lymphocytes enriched through an IFN-gamma capture assay. Nat Med 2001; 7: 1159-62.

[36] Brossart P, Schneider A, Dill P, et al. The epithelial tumor antigen MUC1 is expressed in hematological malignancies and is recognized by MUC1-specific cytotoxic T-lymphocytes. Cancer Res 2001; 61(18): 6846-50.

[37] Jaruga E, Skierski J, Radziszewska E, Sikora E. Proliferation and apoptosis of human $\mathrm{T}$ cells during replicative senescence--a critical approach. Acta Biochim Pol 2000; 47(2): 293-300.

[38] Kalamasz D, Long SA, Taniguchi R, et al. Optimization of human T-cell expansion ex vivo using magnetic beads conjugated with anti-CD3 and anti-CD28 antibodies. J Immunother 2004; 27(5): 405-18.

(C) Kryukov et al.; Licensee Bentham Open.

This is an open access article licensed under the terms of the Creative Commons Attribution Non-Commercial License (http://creativecommons.org/licenses/by-nc/3.0/) which permits unrestricted, non-commercial use, distribution and reproduction in any medium, provided the work is properly cited. 